\title{
Development of Character Education Model in Overcoming Radicalism of Learners
}

\author{
Ahmad Syahid, ${ }^{1}$ Ana Kuliahana ${ }^{2}$ \\ \{ahmad_syahid@iainpalu.ac.id ${ }^{1}$, anakuliahana@gmail.com²
}

Institut Agama Islam Negeri Palu, Indonesia ${ }^{1}$, Institut Agama Islam Negeri Palu, Indonesia ${ }^{2}$

\begin{abstract}
This paper elaborates on the development of character education model in overcoming radicalism of Students in Schools/Madrasas in Palu City. The research method used is Case Study Method to provide a detailed description of the background, traits and characteristics of each school/madrasah studied. The results of the data analysis show that the character education model in SMA/MA in overcoming the radicalism of students is aligned with the PPK movement or Strengthening of Character Education movement, through activities such as Students' organizations, Paskibraka, Youth Red Cross (PMR), Boy Scouts, PIK-Youth (Information Center Health-Youth), Art Studio, Youth Scientific Work, and Sports and also to become criterias for class promotion and student graduation. Thus intracurricular and extracurricular activities in SMA/MA can overcome radicalism in students.
\end{abstract}

Keywords: Character Development, Radicalism, Learners.

\section{Introduction}

Issues in culture and character of nations are becoming the spotlight and attention of every society and various countries, both regarding the aspects of socio-cultural, economic, and also political life which are published on every social media, print media and online media at any time. Indonesia is a country with the largest Muslim population in the world, so it has become the target of political movements in the name of Islam, including the ISIS group [1]. The complexity of radicalism in Indonesia is not easily resolved because it is always associated with upheavals that occured in other parts of the world, for example the Middle East, so that the choice to strengthen the base of nationality in Indonesia by providing understanding and strengthening of nationalism is a long-term solution taken by the government, in addition to a short-term solution. Namely in terms of law enforcement and the strictness of the authorities. Currently, in countering radical movements, all elements of the nation must be involved, both government and society. Without this, it will be difficult to find comprehensive efforts to counter radicalism. The prevention of radicalism is not only aimed at the elites, but also at the lower levels of society including among teachers and students. In this way, the radicalism that is the government's concern can be overcome [2].

Another alternative that can reduce these concerns, can be done through education. Education is considered as one of the alternatives that is preventive because education builds a better generation of the nation [3]. Education are expected to develop the quality of the nation's young generation and to minimize and reduce the causes of various cultural problems and national character. It is acknowledged that the results of education will not have an immediate impact, but it will take time and long endurance in the community.

The results of a survey by the Institute for Islamic Studies and Peace (LaKIP) Jakarta 2010 were truly surprising. As many as $48.9 \%$ of students in Jabodetabek expressed their 
approval of radical action [4]. This result at the same time made teachers, especially Islamic Education (PAI) teachers, realized that there is a danger that threatens their students. Approval or acceptance of a value is the initial stage of the five stages of a person's affective or attitude in the view of David R. Krathwohl, including: (1) receiving, (2) responding, (3) valuing, (4) organizing (organization), and (5) characterization by a value or value complex. This means, if students' consent to radical actions is allowed, it might result in them having a violent personality as a way to achieve goals [5].

\section{Literature Review}

\subsection{Development of Character and PPK Movement}

These parts must not be separated for the. advance of the lives of our children can be perfected. Likewise, the Delors reports for education in the XXI century confirmed that education in the XXI century rests on the five pillars of learning, namely learning to know, learning to do, learning to live together, learning to be and learning to transform for oneself and society. In addition, the National Education System Law No. 20 of 2003, has emphasized that "National education functions to develop capabilities and shape the character and civilization of a nation with dignity in order to educate the nation's life, aiming at developing the potential of students to become human beings who believe and fear God Almighty, have noble, healthy, knowledgeable character. Capable, creative, independent, and become democratic and responsible citizens." In PP No. 19 of 2005, National Education Standards (SNP) expressed various competences related to character as well as intellectuality. These are all indications that education is actually in charge of developing character as well as intellectuality in the form of student competences.

The implementation of national education, especially at primary and secondary education, can be said to be on the right track, because it has provided character education as well as forming intellectuality in the form of competence [6]. Even so, the proportion of the application of character education with intellectual education was not balanced due to various factors. Efforts to balance character education with competency formation must always be done [7]. In the interests of the future of the Indonesian people, even now it is necessary to center character education in the implementation of Indonesian national education [8]. Awareness as well as efforts to focus on character education at the heart of national education was getting firmer when in 2010 the Indonesian government launched and implemented the National Character Education Movement policy based on the National Action Plan (NAP) for National Character Education. This needs to be continued, optimized, deepened, and even expanded so that it is necessary to strengthen national character education. For this reason, the PPK Movement was carried out by observing the principles of sustainability [9].

In this connection, integration can take the form of integrating classroom activities, outside the classroom at school, and outside the school (community); integration of intracurricular, co-curricular and extracurricular activities; simultaneous involvement of school members, families and communities; deepening and expanding can be in the form of adding and intensifying activities that are oriented towards developing the character of students, adding and sharpening learning activities of students, and rearranging the learning time of students at school or outside of school [10]. Furthermore, the adjustment can be in the form of adjusting the main duties of teachers, School Based Management, and the functions of the School Committee with the needs of the KDP Movement. Both in the present and in the future, the integration, deepening, expansion, and alignment of character education programs 
and activities need to be devoted to realizing a mental revolution or a nation's character revolution. Thus, the PPK Movement is a way to manifest Nawacita and the Mental Revolution Movement in addition to being the core of educational activities that directed in the creation of a national character revolution [11].

\subsection{Overcoming Radicalism of Students}

Noermala Sary, reviewing "Preventing the spread of radicalism in schools", the results of the study showed that: the strategies carried out by PAI class teachers in preventing the spread of radicalism in MAN 1 were divided into two types, namely strategies in the learning process in the classroom by using the method of active learning and Qur'anic learning methods, and outside the learning process in the classroom by holding various religious activities, forming worship teams at schools, in collaboration with the police such as Sat. Bintal, and Sat. Binmas, in collaboration with the provincial Ministry of Religion, holds workshops and religious socialization at schools. The supporting factor in the implementation of the strategy to prevent the spread of radicalism in schools is adequate infrastructure, both from learning resources, allocation of learning time and PAI class teachers. Disadvantaging factors are misuse of informatics technology (IT) by students, lack of parental support from school policies, lack of cooperation between schools and student guardians, teachers and guardians of students, and lack of collaboration between teachers [12] [13].

\section{Methods}

The research method used in this article is the case study method developed by Creswell [14]. The research approach used is qualitative descriptive developed by Bogdan and Taylor. Qualitative research is aimed at understanding social phenomena, including in the context of education, from the perspective of participants, namely groups of people or individuals who are interviewed, observed, and where their opinions and thoughts or perceptions are explored.

The research approach is directed at an individual or group setting that is thoroughly observed (holistically), while the setting of the study is in the form of institutions/institutions and individuals. The research was conducted in SMA/MA in Palu City, with a focus on how the model of Character Building activities through PPK (Strengthening Character Education) was developed in SMA/MA in Palu City as research locations and how the implementation results in planting values of Character Growth through PPK (Strengthening Character Education) in students. The subjects of this research includes: Principal of School/Madrasah, Vice Principal responsible for Student Affairs, Teacher responsible of Student Activities, and students.

Initial data on the Character Education Development Model in Overcomng the Radicalism of Students and its implementation, were collected through interview techniques (interview), observation, and documentation. Data analysis was carried out including interactive model analysis (Interactive Model of Analysis). Triangulation is divided into 4, namely: source triangulation, method triangulation, investigator triangulation and theory triangulation. This research was conducted in a normal and natural setting, in various concepts and theories, which were developed based on conditions and facts in the field. To measure the validity of the data, the technique of checking the validity of the source triangulation data was used. Source triangulation is a method of checking the validity of data by comparing and 
cross-checking the degree of confidence of information obtained through different time and tools in qualitative methods. The data obtained are in the form of interviews (interviews) which were conducted more than once in a certain period of time. Data analysis was carried out in a staged and interrelated between the reduction of schools/madrasahs and outside schools/madrasahs. For this reason, the Development of Character Education in Overcoming the Radicalism of Students in schools/madrasas is an important case to do, so that the expected goals which are to minimize and eliminate radicalism of students can be realized.

\section{Results and Discussion}

The Development of Character Education in Overcoming the Radicalism of Students in schools/madrasas throughout Palu City is carried out in several stages and activities:.

\subsection{Planning, Implementing and Strengthening of Character Education}

Planning, Implementing and Strengthening Character Education in SMA / MA in Palu City is carried out in stages and adjusted to the needs and conditions of the school. PPK has encouraged the quality of education of students as part of the National Movement for the Mental Revolution in. education. SMA Negeri 4 Palu has many extracurricular activities, including: (1) OKTOBER Theater, (2) Environmental Organization "PALADAKA" (now PLASMA), (3) Paskibra, (4) Basketball, (5) English, (6) Islamic Spirituality (Rohis), (7) Christian Spirituality (Rohkris), (8) Youth Red Cross (PMR), (9) Youth Scientific Creation (KIR), (10) Football, (11) Scouts, (12) Pencak silat, (13) Karate, (14) Bamboo Music, and (15) Table Tennis.

Furthermore, the Principal of SMA Negeri 4 Palu explained that "PPK is integrated in the curriculum and in the Vision and Mission of SMA Negeri 4 Palu for the last 3 years, but actually, the implementation was carried out long before the implementing 2013 Curriculum (K13). In K13 it is implicitly conveyed that the character education of students is emphasized in the criteria for class promotion and graduation. So actually it is very clear that possessing character is one of the requirements for graduation".

This was also explained by the principal of MAN 1 Palu, that "PPK was implemented, before the 2013 Curriculum (K13) existed, but it was strengthened since K13 was stated in the Learning Implementation Plan (RPP), integrated in all subjects".

From the explanation of the principal of SMA Negeri 4 Palu and MA Negeri 1 Palu, it can be seen that the implementation of Character Development through PPK, especially in Overcoming Radicalism in Students was carried out before the implementation of the 2013 Curriculum, PPK is implicitly integrated in the curriculum and in the vision, mission of SMA Negeri 4 Palu, and implementation was carried out before 2013 when it was declared in the 2013 Curriculum (K13)

What was implemented at SMAN 4 Palu and MAN 1 Palu City was also been carried out in MAN 2 Palu City, "we plan and integrate the values of character in the curriculum and in the vision and mission of MAN 2 Palu. The Student Program of MAN 2 Palu City includes: (1) Implementing the discipline and culture of madrasas. (2) Carry out mutual cooperation and community service (joint service). (3) Implementing the norms and social manners. (4) Planting awareness to be willing to sacrifice for others. (5) Planting an attitude of respect and respect for madrasa citizens, (6) Carrying out $7 \mathrm{~K}$ activities (security, cleanliness, order, beauty, family, peace, and shady)". 
Meanwhile at MA Alkhairaat Palu, the pricipal of MA Alkhairaat Palu explained: "The implementation of Character Building among MA Alkhairaat Students is planned in the RPP and carried out in the subjects of Aqidah Akhlak (for all majors) and Morals (especially in the Department of Religion). In addition to the subject of character building, it is also programmed in various student organizations, including: Paskibraka, Youth Red Cross (PMR), and Boy Scouts, PIK-Youth (Health-Youth Information Center) in collaboration with BKKBN, Art Studio, Youth Scientific Work, and Sports

To find out the implementation in SMKN 2 Palu, the vice principal of SMKN 2 Palu explained, "Implementation of Character Growth through PPK in overcoming Radicalism in Students at SMKN 2 Palu is by integrating moral values in subjects in all subjects and extracurricular activities."

The implementation of KKP in SMA/MA throughout Palu City as explained by the principal of schools/madrasahs is carried out with three main approaches, namely class-based, school culture-based, and community-based. These three approaches are interrelated and form a whole. This approach can assist educational task force in designing and implementing PKK programs and activities The implementation of character building through PPK in SMA/MA has been carried out prior to the existence of the PPK Movement, which was implemented by the Ministry of Education and Culture by strengthening the character of the nation's successor through the PKK movement launched in 2016, because PPK is a continuation of the National Movement for National Character Education 2010 launched by the government [9]. The implementation and strengthening of Character Growth through PPK has been implemented and integrated in the subject and included in the RPPs The implementation of character building through PPK in SMA/MA in Palu city refers to the five main character values that come from Pancasila, and is a priority for the development of the PPK movement. Each PPK value does not stand and develop independently, but interact with each other, develop dynamically and form personal wholeness a. Religious

The growth of religious values in students at SMAN 4 Palu is included in the extracurricular activities of Rohani Islam (Rohis), one of which requires each student to pray together in mosques, especially dzuhur prayers. "The character education that we set to students at SMAN 4 Palu, includes strengthening in the field of spiritual development through: extracurricular spirituality of Islam (Rohis) every day and students always pray Dzuhur together. The PAI teacher after dzuhur prayer gives tausiah or kultum, and sometimes students take turns, the goal is to instill character values as a reflection of devotion to Allah SWT."

This is in line with one of the goals of religious character values, namely as a form of reflecting faith in God Almighty, implementing religious teachings and beliefs, respecting religious differences, upholding a tolerant attitude towards the implementation of religious worship and other beliefs [15], living in harmony and peace with other religions [5][16]. The implementation of these religious character values is shown in an attitude of peace-loving, tolerance, respect for differences in religion and belief, strong determination, confidence, cooperation between followers of religions and beliefs, anti-bullying and violence, friendship, sincerity, not imposing one's will, loving the environment, protecting the small and marginalized groups [17].

\section{a. Nasionalism}

As a form of planting a sense of nationalism among students, the principal of SMA/MA requires each student to be active in activities carried out by student organizations, and is an official forum in SMA/MA, including: (1) Paskibraka, (2) Red Cross Youth (PMR), and (3) 
BoyScouts. "Boy Scout extra-curricular activities (Scout eskul) are carried out as a form of strengthening the spirit of nationalism for students".

The purpose of carrying out the activities of Paskibraka, Youth Red Cross (PMR), and (3) BoyScouting, is to develop the nationalist character values of students so that students think, behave, and act by showing loyalty, concern, and high appreciation for differences in language and environment. physical, social, cultural, economic status among students, to place the interests of the nation and the state above the interests of individual and their groups [18]. This nationalist attitude is shown through an attitude of appreciation of the nation's own culture, maintaining the nation's cultural wealth, being willing to sacrifice, excellent, patriotic, protecting the environment, obeying the law, discipline, respecting cultural, ethnic and religious diversity .

\section{b. Integrity}

One of the efforts made in developing the value of integrity character among SMA/MA students of Palu City is to include students in Student Organizations, as explained by Vice Principal of MA Alkhairaat Palu: "Student organizations in the MA Alkhairaat Palu Center are called 'Student Association. Islam Alkhairaat' which is known as PPIA. This organization is equivalent to the Students' Union (OSIS) in several schools or madrasah. Student work programs are compiled and implemented in the form of activities for 1 year in 3 main divisions, namely: (1) Field Work Program, (2) Cross Sector Work Program, and (3) Collective Work Program".

The purpose of involving students in Student Organization is a form of implementation of integrity character values. This is in line with the objectives of the integrity character value, a value that underlies behavior based on efforts to make himself a person who can always be trusted in words, actions, and work, and has a commitment and loyalty to human and moral values. The character of integrity includes an attitude of responsibility as a citizen, actively involved in social life, through consistency of actions and words based on honesty. A person with integrity also respects the dignity of the individual (especially persons with disabilities) and is able to show exemplary.

\section{c. Independence}

Independent character values are attitudes and behaviors that are not dependent on others and use all energy, thoughts, time to realize hopes, dreams and ideals. Independent students have a good work ethic, are tough, have a fighting spirit, are professional, creative, have courage, and are lifelong learners [7].

\section{d. Cooperativeness}

The value of the cooperatif character applied to students in SMA/MA is by reflecting the act of appreciating the spirit of cooperation and working hand in hand to solve mutual problems, establishing communication and friendship, providing assistance to people in need. It is hoped that students can show respect for others, be able to cooperate, be inclusive, be able to commit to mutual decisions, discussion, helpful, have empathy and a sense of solidarity, anti-discrimination, anti-violence, and an attitude of volunteerism. 


\section{e. Class-Based PPK}

Class-based PPK is carried out by integrating PPK in the curriculum. The integration of PPK in the curriculum means that educators integrate the main values of PPK into learning of every subject. Learning that integrates the main values of character is intended to grow and strengthen knowledge, instill awareness, and practice the main values of PPK. Educators can optimize the use of the material that is already available in the curriculum contextually by reinforcing the main values of PPK [9].

The steps of implementing PPK through integrated learning in the curriculum can be carried out by: (a) conducting a basic competency analysis by identifying the values contained in the learning material; (b) designing lesson plans that focus on strengthening character by selecting relevant classroom learning and management methods; (c) carrying out learning activities according to the scenario in the lesson plan; (d) carrying out authentic assessment of the learning results; and (e). reflecting and evaluating the entire learning process. Implementation of Strengthening Character Education (PPK) in SMA/MA/SMK Palu in developing admirable behavior of students is carried out by various activities in the work program.

\section{f. Strengthening Character Education Based on School Culture}

Strengthening Character Education Based on School Culture in SMA/MA/SMK Palu based on: (1) Emphasizing the habituation of the main values in daily school activities. (2) Highlighting the role models of adults in educational settings. (3) Involving the entire educational system in schools. (4) Developing and providing wide space for all potential students through co-curricular and extra-curricular activities. (5) Empowering school management and governance. (6) Considering school norms, rules and traditions. Reflected in school/madrasah activities such as routine morning coordination every day before class, worship hours before school is over, and penalties for students who violate school rules.

The implementation of activities at schools/madrasah involves all elements in the school/madrasah, not only the principal, but also all teachers, administrative staff, students. The implementation of these activities which have become a culture in SMA / MA in Palu City is familiarized with the introduction and application of ethical values and character, including discipline, because discipline is part of character. Discipline is related to discipline at school and is strengthened in oral and written forms as well as practice in the field in daily school / madrasah activities.

As an explanation of the work program at SMA Negeri 4 Palu, it has referred to the five main character values which are interrelated and developed as a priority for the PPK movement. The five main values of national character in question are religious. Religious character values reflected in faith in God Almighty which is manifested in the behavior of implementing religious teachings and beliefs, respecting religious differences, upholding a tolerant attitude towards the implementation of religious worship of other beliefs, living in harmony and peace with other religions.

Same as students at SMA Negeri 4 Palu where students are enthusiastic to carry out jamaah prayers, especially $d z u h u r$ prayers. This is confirmed by the statement of the principal of SMA Negeri 4 Palu as follows: "During the dzuhur prayer, students hasten to do jamaah pray and the teacher controls all students, the implementation of $d z u h u r$ prayer is routinely carried out. Dakwah by participants and teachers are sometimes performed after Dzuhur Prayer. Whereas in MAN 1 Palu, the management of worships at the Mosque Centre are 
strengthening or special study related to Islam. Referring to the curriculum set forth in the lesson plan for each teacher in all subjects, it is hoped that it can integrate and provide understanding and be able to accept any differences that exist in each student in learning activities outside the classroom

\subsection{Theological, Sociological, and Psychological Implications of Overcoming Radicalism of SMA/MA Students}

Several research results in educational institutions show data and facts that radicalism movements and networks have long been infiltrating educational institutions. Students are very venerable or have limited understanding of religion, and are psychologically looking for self-identity and become perfect target of radicalism. Through this radical movement, indications have emerged in several educational institutions that have the potential to become a center for the growth of intolerance, exclusivity, anti-diversity, and even violence. In some cases, school institutions have even been seen to encourage and even facilitate the growth of radicalism and extremism which tend to be intolerant of differences, discriminatory, rejecting democracy, and are anti-human rights [3].

\section{a. Theological Implications}

In the context of thoughts about the radical understanding of the Qur'an and hadith, it will result in several tendencies, namely theological fanaticism and divisions, radicalism or the emergence of fundamentalist movements and even terrorism. Radicalism will give rise to intolerance that arises in relation to issues of religious teachings. In the theological perspective, a mistake in interpreting religious teachings creates selfish attitudes and arrogance and to assume groups that are different from their understanding are wrong. This shows that the SMA/MA/SMK environment in Palu City has not been infiltrated with radical religious understanding.

\section{b. Sociological Implications}

Deviant behavior is all actions that stray from the norms prevailing in a social system and cause efforts from the authorities in that system to correct the deviant behavior. In this context, principals of SMA/MA/SMK in Palu City, at any time during the study always pay attention and observe the behavior of students in SMA/MA/SMK in Palu City, until there has been no influence that leads to radicalism, and have never received reports of students being involved in activities related to radical groups. If any indication is found, we will provide special guidance.

\section{c. Psychological Implications}

The emergence of the phenomenon of religious radicalism cannot be separated from the psychological problems of both its pioneer figures, followers and society at large. The problem of religious radicalism gave birth to anomalous values in society. Religious radicalism "describes an anomaly as well as the possibility of social derivation, namely that there is always an abnormal community. Either they are in a demographic abnormality or a psychological abnormality." The implications of the steps of religious guidance by SMA/MA/SMK in Palu City are: (1) the development of the understanding of radical Islam 
does not have a strong influence on the religious understanding of students in SMA/MA/SMK in Palu City. (2) It has not been seen clearly that there are individuals and groups in SMA/ MA/SMK in Palu City who are fanatical and sentiment towards other groups."

Efforts made in planting Characteristic values through Strengthening Character Education (PPK) for students in overcoming Radicalism in MAN 1 Palu City are packed in the form of extracurricular activities, including: sports (Judo, basketball, futsal, taekwondo), MTQ, Safety Riding Education, etc.

\section{Conclusion}

Planning for Character Development through Strengthening Character Education in Overcoming the Radicalism of Students in SMA/MA throughout Palu City is already integrated in the curriculum as well as in the vision, mission, and implementation long before 2013 curriculum at SMAN 4 Palu. In the 2013 curriculum, character education implicitly emphasizes the criteria for class promotion and graduation criteria. PPK was implemented in several schools/madrasahs prior to the implementation of the 2013 Curriculum (K13), but has been strengthened since the implementation of $\mathrm{K} 13$ are outlined in the Learning Implementation Plan (RPP), and integrated in all subjects

The implementation of Character Development through Strengthening Character Education in overcoming the Radicalism of Students in SMA/MA in Palu City, especially in madrasah aliyah is integrated in the subjects of Aqidah Akhlak (for all majors) and Morals (especially for the Department of Religion). In addition to subjects, character development is also programmed in various student organizations, including: Paskibraka, Youth Red Cross (PMR), Boy Scouts, PIK-Youth (Center for Health-Youth Information) in collaboration with BKKBN, Art Studio, Youth Scientific Work, and sports. Student organizations in the MA Alkhairaat Central Palu are known as PPIA. This organization is equivalent to the OSIS in several schools or madrasah. Student work programs are prepared and implemented in the form of activities for 1 year in 3 main areas, namely: (1) Field Work Program, (2) CrossSector Work Program, and (3) Collective Work Program. Character education of students at SMAN 4 Palu, among others, is strengthening in the field of Spiritual Questioning development through: Islamic spiritual extracurricular activities (Rohis) every day and students always carry out daily activities in the mosque with Dhuhur Jamaah prayers. The teacher of Islamic religious education lecturers did have skills in using digital media but because of a sudden policy changes, they are still in the early stage of adjustment that causes the lack of readiness in applying online learning during a pandemic covid-19. In other hands, senior lecturers are more heavily affected by the impact of distance learning because of the inability to use digital media. This resulted in monotonous learning methods. This factor causes the evaluation of lecturers' online learning performance results during the Covid-19 pandemic to be less effective.

The implications of the steps of education and religious development by SMA / MA / SMK in Palu City are: (1) the development of understanding of radicalism does not have a strong influence on the religious understanding of students in SMA / MA / SMK in Palu City. (2) It has not been seen clearly that there are individuals and groups within SMA / MA / SMK in Palu City who are fanatical and sentiment towards other groups. Also, there are no indications in individuals and groups of psychological abnormalities. Students still show common attitudes without any abnormalities from interactional patterns, both to teachers and to fellow students 


\section{References}

[1] Ridwan, "Hubungan Islam dan Politik di Indonesia Perspektif Pemikiran Hasan al-Banna," J. Huk. Samudra Keadilan, vol. 12, no. 2, pp. 223-236, 2017.

[2] saihu dan marsiti, "PENDIDIKAN KARAKTER DALAM UPAYA Institut PTIQ Jakarta Sekolah Menengah Atas Negeri 3 Depok Abstrak," Pendidik. Islam, vol. 1, no. 1, pp. 23-54, 2019.

[3] T. Syahlan, "Menangkal Gerakan Radikalisme Islam Melalui Sekolah," MAGISTRA Media Pengemb. Ilmu Pendidik. Dasar dan Keislam., vol. 6, no. 2, pp. 1-15, 2018.

[4] I. Akuntono, "Mendiknas: Perlu Pendidikan Karakter untuk Tangkal Radikalisme," Kompas.com, Jakarta, 2011.

[5] M. Al Al-Hasyimi, Muslim Ideal; Pribadi Islami dalam al-Qur'an dan as- Sunnah. Yogyakarta: Mitra Pustaka, 2004.

[6] A. Mudlofir, Pendidik Profesional: Konsep, Strategi dan Aplikasinya dalam Peningkatan Mutu Pendidik di Indonesia. Jakarta: Rajawali Pers, 2013.

[7] T. Lickona, Educating for Character: How Our School Can Teach Respect and Responsibility. New York: Bantam Books, 1992.

[8] I. Fathurrochman and E. Apriani, "Pendidikan Karakter Prespektif Pendidikan Islam Dalam Upaya Deradikalisasi Paham Radikal," POTENSIA J. Kependidikan Islam, vol. 3, no. 1, p. 122, 2017.

[9] TIM PPK Kemendikbud, "Panduan Penguatan Pendidikan Karakter Tingkat SD dan SMP," kemdikbud.go.id., p. 1, 2020.

[10] D. Koesoema, Pendidikan Karakter Strategi Mendidik Anak Secara Global. Jakarta: Grasindo, 2007.

[11] Z. Daradjat and Dkk., Ilmu Pendidikan Islam. Jakarta: Bumi Aksara, 2014.

[12] T. T. Az-Zarnuji, Ta"limu al-Muta"allim. Surabaya: IMAM. Balitbang Pusat Kurikulum Kemendiknas, 2010.

[13] C. S. Bamualim and G. A. Ahmad, Mekanisme Pencegahan Terorisme di Daerah. In Modul Pencegahan Terorisme di Daerah. Jakarta: BNPT, 2013.

[14] J. W. Creswell, Desain Penelitian. Pendekatan Metode Qualitataive, Quantiative dan Mixed. Lincoln: Sage Publications, 2014.

[15] M. T. Hasan, Islam dalam Perspektif Sosio Kultural. Jakarta: Lantabora Press, 2005.

[16] N. Uhbiyati, Dasar-Dasar Ilmu Pendidikan Islam. Semarang: FITK IAIN Walisongo, 2012.

[17] Lajnah Pentashihan Mushaf Al-Qur"an., Hubungan Antar-Umat Beragama (Tafsir Al-Qur"an Tematik). Jakarta: Aku Bisa, 2012.

[18] T. Priatna and T. Ratnasih, "Counteracting Radicalism through Islamic Religious Learning with Nationalist Insights,” Talent Dev. Excell., vol. 12, no. 1, pp. 2204-2214, 2020. 